\title{
Exploring Partnerships between Local Communities and Timber Companies: An Experiment Using the Role-Playing Games Approach
}

\author{
Herry Purnomo, ${ }^{1}$ Philippe Guizol, ${ }^{2}$ and Guillermo A. Mendoza ${ }^{3}$ \\ ${ }^{1}$ Center for International Forestry Research (CIFOR) and Department of Forest Management, Bogor Agricultural University, \\ Bogor 16680, Indonesia \\ ${ }^{2}$ Centre de Coopération Internationale en Recherche Agronomique pour le Développement (CIRAD) and Center for \\ International Forestry Research, Bogor 16000, Indonesia \\ ${ }^{3}$ Department of Natural Resources and Environmental Sciences, University of Illinois, Urbana, IL 61801, USA
}

Correspondence should be addressed to Guillermo A. Mendoza, gamendoz@uiuc.edu

Received 1 October 2008; Revised 19 December 2008; Accepted 19 January 2009

Recommended by Guofan Shao

Cooperation among stakeholders is widely accepted as an effective management strategy. This paper describes an experimental study that explores this cooperation using role-playing games, which is formulated within a multiagent simulation framework. This framework enables participants to take active roles in mimicking the collaborative decision environment and the behaviors and attitudes of the different stakeholders. The paper examines a forest plantation company in South Sumatra, Indonesia, which has cooperated with local communities since 2000. The experimental pilot study described in this paper explored the role of communication in partnership relationships between the company and the local communities living within and around the surroundings of the company's plantation. These partnerships were explored and analyzed using the gaming approach involving university students taking the role of forest stakeholders, from both the timber company and the local communities. Lessons learned from the game provided the rationale for the establishment of a communication institution called "Forum Sebahu Sejalan." This formal forum was constituted after a facilitated ex-postinteraction between representatives from the timber company and local communities. Results and observations drawn from the interactions show the potentials of the RPG approach and the formal forum in crafting resilient partnerships among stakeholders.

Copyright () 2009 Herry Purnomo et al. This is an open access article distributed under the Creative Commons Attribution License, which permits unrestricted use, distribution, and reproduction in any medium, provided the original work is properly cited.

\section{Introduction}

Principle 22 of the 1992 Rio Declaration on Environment and Development highlights the importance of local people and their participation in sustainable development. In forestry, this often applies to indigenous people or communities living within or nearby forest concession areas. Consequently, participatory management approaches have been devised to strengthen the capacity of local forest communities and enhance their capability to be engaged in participatory management. These approaches often involve different ways of empowering local communities by allowing them to be actively involved in planning and decision making. This paper describes an experimental pilot study that examined participatory man- agement using role-playing games (RPG) formulated within a multiagent simulation framework where participants take active roles mimicking the collaborative decision environment and the behaviors and attitudes of the different stakeholders.

1.1. Forest Plantations, Pulp Industries, and Land Disputes. Indonesia's pulp and paper industry has rapidly expanded since the late 1980s. The 1998 economic crisis temporarily slowed the rate of expansion, but by 2000 several pulp mills were established. Disputes over land between local and customary communities and forest companies during the Soeharto era (i.e., New Order regime, 19661998) were suppressed by military force. Soeharto's resignation, and the subsequent political transition in May 
1998, spawned the beginning of community movements demanding that customary rights be restored, including communal land rights. Conflicts arose as local communities and companies clashed over (1) the land appropriation process, (2) environmental impacts, and (3) recruitment of employees [1].

1.2. Multiagent Simulation and Role-Playing Game. For better management planning purposes, forestry planners and policy makers should be able to assess the long-term impacts of major activities or policies such as establishing plantations, or cooperation among stakeholders. Simulation is one way to explore long-term impacts; in fact, it may be the only viable tool for making impact assessments particularly if the forest system is large or too complex. Simulation generally involves the process of developing a simplified representation of a real-world situation (called the simulation model), and "animating" it so that stakeholders can envision future scenarios.

Multiagent simulation (MAS) is a promising tool for examining natural resource management alternatives, and for analyzing environmental management issues [2]. MAS has desirable features that make it an appropriate "analytical platform" for the participatory natural resource management. It is flexible and can accommodate many stakeholders, and it is robust enough to embrace different management options and types of decision-making procedures and processes.

In general, cooperation among stakeholders can occur naturally only when individuals cannot pursue their goals on their own. Agents or actors may communicate among themselves when they are interested to seek cooperation in order to achieve a shared goal $[3,4]$, even when economic, social, or political objectives may differ. Cooperation is a dynamic concept that evolves over time, but may or may not survive broader economic and social trends and changes. Hence, Axelrod and Cohen [5] have examined the need for adaptive capacities among all stakeholders involved in the cooperative process.

Information and communication technology has made the world an increasingly complex, yet smaller, place. Forest stakeholders now have better access to information. They also view themselves and others to have to deal with more variables, issues, and concerns in order to manage their forests more effectively. With more and better information, forest stakeholders are now in a position to examine and possibly improve cooperative arrangements and institutions. While cooperation should be adaptive, it also needs a certain amount of resilience to be effective in a dynamic world. Roleplaying games (RPGs) are a useful approach to scrutinize partnership and cooperative arrangements and examine the capacity for adaptation.

In general terms, a game is an action that triggers a reaction, which then triggers further action and more reaction. COMMOD [6] defined a game as (a) a free activity, (b) having imaginative components, (c) bounded by space and time, (d) a trigger group discussion, and (e) a mimic normal behavior. Behind a game is a body of knowledge called "game theory," which spells out how rational individuals make a decision when they are interdependent. In game theory, individualism, rationality, and interdependency are some of the basic theoretical constructs that predicate the behavior and dispositions of the players [7].

Role-playing game is specifically designed for the interaction between players based on the roles they play $[8,9]$. Through the RPG, one can observe the way roles are played, how actions and decisions of players impact other players' behavior and decisions, and the impacts to the decision environment. During the game, each player is allowed to act collectively, to contribute in creating new institutions or rules among the players, or to achieve common goals. When the game is over, each player can analyze the lessons learnt and compare the game to the real world. The game's realism may take one of several forms (a) explicit reality, where RPG presents the actors' real situation and their resources; (b) implicit reality, where RPG represents a simplified version of actors and their resources; (c) virtual world, where RPG is based on an issue which is not necessary related to a specific actor or resource [6].

Ostrom et al. [9] distinguished between cooperative and noncooperative games. In cooperative games, players can communicate freely and make enforceable agreement; in noncooperative games, they can do neither. Communication and information sharing among players may produce collaboration. Cárdenas and Ostrom [10] proposed three layers of information in deciding about their level of cooperation in three rural villages of Colombia. The layers range from material incentives to the composition of the group and the individual characteristics of the player.

Recognizing the importance of collective action in natural resource management in developing countries, MeinzenDick et al. [11] provided an overview of studies that present applications of qualitative, quantitative, experimental, and action research methods including experimental games for studying collective action. Pacheco et al. [12] promoted the capability of a game to develop a strategy to help organizations deal with various challenges, and also as a strategy to increase global awareness about environmental issues and to build environmental responsibility. The game is an innovative tool that can be used to develop a coordinated strategy among different actors. Such strategy may also lead to the development of new institutions and revitalize existing ones. For instance, Atran et al. [13] described how actors with different mental models of conceptualizing nature affect their behaviors, strategy, and actions. These mental models have implications for environmental decision-making and management, including forestry common property problems.

The failure of forest owners and managers to prohibit user groups from exploitative extraction of forest resources has forced them to opt for a collaborative management approach, termed as joint management [14] or out-grower scheme in forest plantations [15]. Platteau and Gaspart [16], however, have indicated that the main difficulties of community-driven development lie in their vulnerability to situations where local elites capture much of the benefits. It has also been noted that too quick and massive rush to community-driven development may prove self-defeating 
in the sense that benefits actually reaching the poor may be lower than expected if donor agencies are impatient and do not allow time for institutions to develop [16]. Local democracy often shapes social and environmental sustainability. Representation in decision making, a trademark of democracy, is the mechanism that can lead to efficiency, equity, and the elusive sustainability goal promised by decentralized and community-oriented forms of natural resource management. One prerequisite condition of this representation in decision-making is local peoples' capacity to participate and capability to engage the local elite [17].

Enhancing the capacity of local communities requires the establishment of enabling institutions which have to be perceived as credible by social actors. In other words, institutional functionality relies on its social acceptability or credibility [18]. Focusing on institutions is also advocated by Agrawal and Gibson [19], who suggested that concentrating on institutions rather than the community is likely to be more fruitful and effective in advancing community-based natural resource management.

1.3. Context of Pilot Study. Musi Hutan Persada (MHP) is an Acacia mangium plantation company located in South Sumatra, Indonesia. MHP is a joint venture composed of the state-owned company Inhutani II and the private companies Barito Pacific Timber, Muktilestari Kencana, and Marubeni Corporation. MHP operates under the Indonesian Minister of Forestry Decree No. 38/Kpts-II/1996, dated 29 January 1996. The MHP plantations cover a total of 296400 hectares across three noncontiguous sites in South Sumatra (see Figure 1).

Communities surrounding MHP are mostly made up of traditional farmers. Other members of the local communities are MHP workers, traders, and local government officials. The farmers grow rubber, rice, and Acacia mangium in collaboration with MHP. The local people customarily organized themselves according to the traditional "Marga" system. Based on customs and traditions, the "Marga" system generated communal rules and norms for utilizing resources in a specific territory. This system broke down in the early 1980s; consequently, collective livelihood actions are now rare.

In 1998, Indonesia faced an economic, social, and political crisis due to the political transition that ensued following the change in political power at the national level. The crisis affected all development sectors, including MHP forest plantations which were established two years earlier. Villages surrounding the plantations began to ask MHP for more benefits, or for their share from the company's economic profits derived from extracting timber from the forest. This led to conflict between the company and local people. To ease tensions, MHP developed two cooperative schemes: "Managing Forest with Community" (MHBM or Mengelola Hutan Bersama Masyarakat) and "People Forest Management" (MHR or Mengelola Hutan Rakyat).

The MHBM area is about 40000 hectares and involves 12 villages. In this scheme, the timber company pays the communities some royalty fees from the MHP plantations on its concession land. The fee amounts to Rp. 2500 $(\mathrm{US} \$ 1$ = Indonesian rupiahs 11000 (Rp. or IDR)) per cubic meter of log. Although MHBM is called a partnership scheme, it was found that the scheme involves MHP giving direct aid to the communities.

MHR is closer to the partnership spirit, with an outgrower scheme for smallholder plantations. The MHR area is about 4000 hectares and involves eight villages. Individuals or groups can propose to MHP to plant trees on their own land, regardless of its status. If MHP approves, the company will provide all establishment and maintenance costs for small plantations from 2 to 100 hectares. Profits are shared $60 \%$ to MHP, and $40 \%$ to the individual or group.

\section{Development of the Game}

In the case study, villagers living around the MHP plantations may or may not participate in a partnership in seven different ways (a) small-scale Acacia mangium cultivation (out-grower scheme), (b) planting rubber, (c) maintaining old rubber, (d) growing oil palm, (e) providing labor for MHP, (f) growing small-scale mixed-plantation, and (g) looking for rent opportunities. By comparison, the company manages its big Acacia plantation, participates in the partnership, and manages its employees.

The game's goal is to improve local welfare by giving communities an insight into how to construct their livelihood strategies. The objectives are (a) to share knowledge with local communities about livelihood strategies and (b) to help collective decision making on self-organization, cooperation, and coordination to achieve the common goal.

The general modeling process and the pilot study followed the following steps: (a) represent the MHBM and MHR in the game; (b) test and engage the stakeholders in refining the model; (c) conduct role-playing game; (d) develop future scenarios; (e) develop rational collective plans and actions. This paper describes the experiment conducted under the first four steps. To facilitate the modeling process, a "companion modeling approach" with a modeling tool, namely, Common Pool Resources and Multi-Agent System (CORMAS) was adopted. CORMAS is a multiagent simulation platform specifically designed for renewable resource management systems [20, 21].

Prior to developing the game, the authors visited the sites and had several discussions with stakeholders to get a firsthand understanding of the context. This game is to be played at the community level; in other words, the community's perspective is at the core of the game. The stakeholders were identified according to the following criteria: proximity to the forest, legal or traditional rights over the forest, and dependence on the forest.

The game used implicit reality, meaning it is based on a simplified representation of actors, resources, and land management relevant to the players, in this case MHP. This approach offers more advantages than explicit reality in terms of (a) avoiding issues sensitive to some community members, such as the boundary between community and MHP land and (b) providing higher flexibility in the game. 


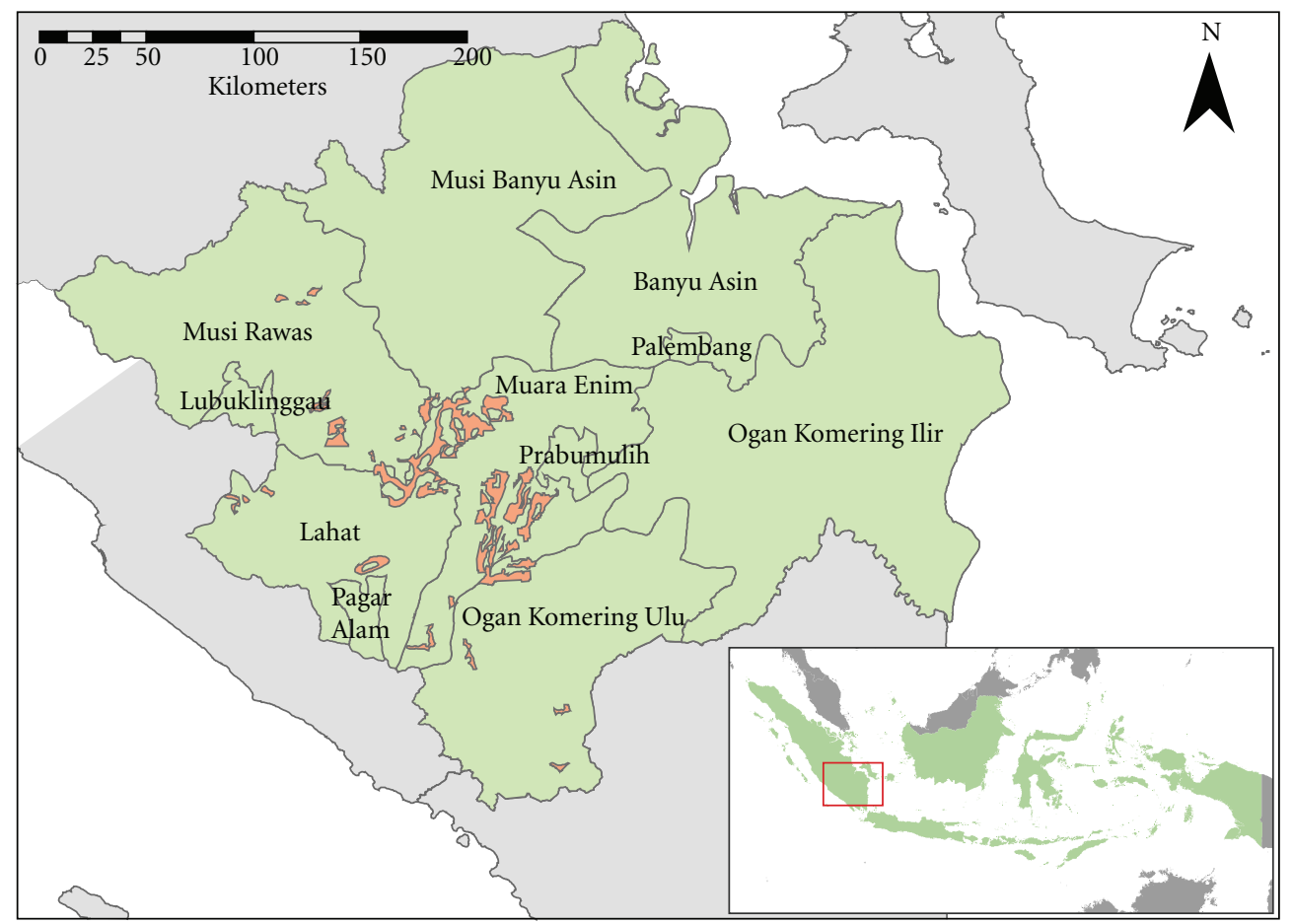

Musi Hutan Persada concession

District boundary

FIgURE 1: MHP's forest plantation concession in South Sumatra Province (inset Indonesia).

Two types of stakeholders were identified, namely, the local communities, and the MHP with its land concession planted with Acacia mangium. In formulating the "rules" of the game, the focus was more on the roles of the communities in the partnership rather than MHP. Some of the community members have traditional lands so that they can enter into MHR partnership, or grow trees such as rubber and oil palm. Community members without land can work as laborers of MHP, rubber tappers, or do off-farm jobs.

2.1. Spatial Setting of the Playing Field. Figure 2 describes the spatial setting of the game. The spatial context of the game is a landscape that comprises 25 cells. Each cell represents 10 hectares. There are two land categories, namely, company Acacia plantation and the community's small, old, and unproductive rubber plantations.

2.2. Players and Their Decision Spaces. There are two categories of community players: villagers with, and villagers without land. They are all located within the communities. The game is played with six people as landowners (LOs) and four as nonland owners (NLOs). The proportional numbers of LOs and NLOs were intended to balance power and reflect real situation in the field.

LOs may manage their land, participate in MHBM, and work for the company, or become company laborers. These three options are not mutually exclusive. It means that they

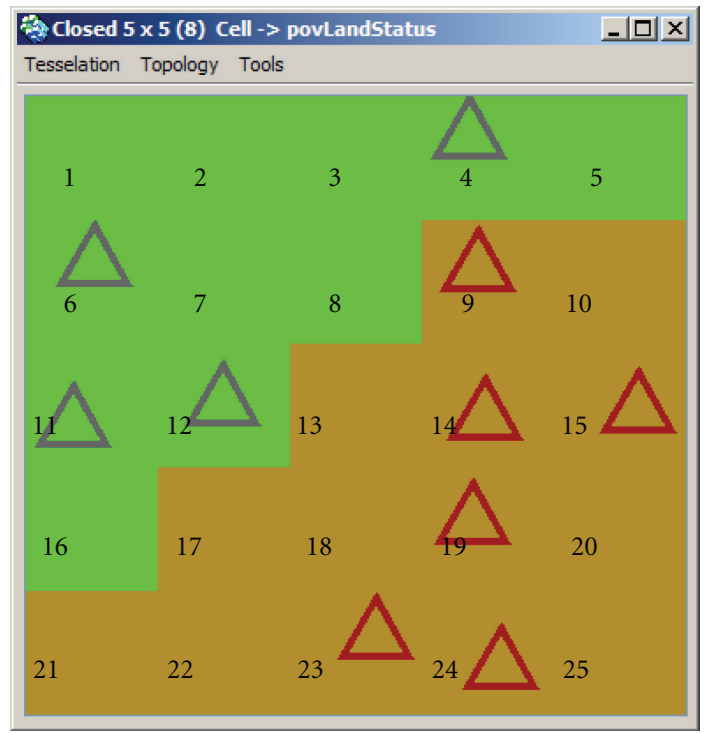

FIGURE 2: Game spatial setting with community land (bottom) and MHP forest concession (top).

may choose more than one option at the same time. The first option, managing the land, comprises three suboptions: keeping the old rubber trees, selling the land, or replanting 


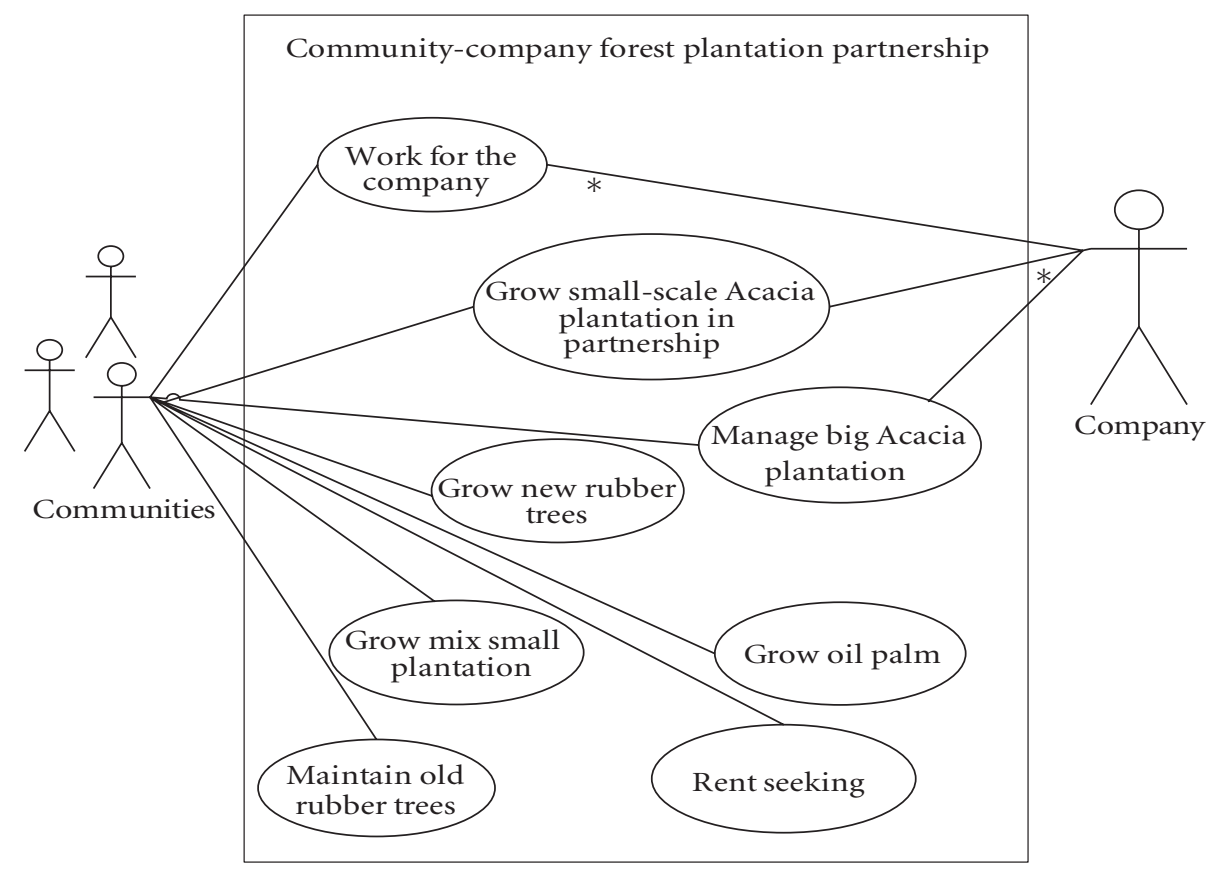

Figure 3: Use case diagram of the game.

it with Acacia mangium, oil palm, a new rubber variety, or mixed plantation.

NLOs do not have many options. NLOs may participate in MHBM or provide company labor. Both LOs and NLOs may also become free riders or rent seekers in this game. Table 1 shows a simplified payoff for managing the land for over 20 years. The simple payoff table describes the investment (I) and economic return (R) at the strategic level represented by the strategic choices available to the villagers with and without land. Hence, the payoff table shows the amount invested when the strategic option is chosen, and the expected return from the strategic option at a given time in the future (e.g., rotation). In the case of the MHBM partnership scheme, there is no investment required from the local community to get a return of rupiahs 5 million (i.e., royalty) at the end of an Acacia eight-year rotation. MHR partnership scheme requires land and investment of Rp 2 million at the beginning of the year in order to gain a return of $\mathrm{Rp} 80$ million at the end of the rotation. Preserving old and unproductive rubber plantation costs nothing but it will produce insignificant income. Investing in new varieties of rubber and oil palm involves significant costs estimated at about rupiahs 60 million which is generally unaffordable for individual farmers although such investment can yield significant economic returns. Mix plantation takes longer rotations than an acacia plantation, but it can yield higher values particularly with respect to biodiversity.

In this experiment, the game is intended to represent the local community's strategies in improving their livelihoods under options and rules created by MHP such as MHR and MHBM partnership arrangements. It also provides a way to analyze how communication and collaboration can improve the local community's livelihood strategies. It focuses on the dynamic relationships among local communities rather than with MHP. Hence, the company at this RPG stage is perceived as "typical" or in a "ceteris paribus" sense.

The company can play roles such as: reformulating the benefit-sharing arrangement of MHBM and MHR, considering planting options other than Acacia, or changing the acceptance number of MHR applicants. In the current game, MHP only accepts four players with MHR proposal applications, which represents, and is commensurate with, the limit of MHP's funding for joint venture with local communities. MHP can increase this limitation by accepting more MHR proposals. In such cases, the local community, as rational players, can react by implementing a different strategy as they attempt to maximize their benefit in light of the company's changing policy.

2.3. Playing the Game. The diagram of the game context is shown in Figure 3. The figure represents a forest plantation partnership within a bounded system with the categories of actors involved: communities, and the company, in this case the MHP. The different options for local communities and the company are also described.

Initially, each player has 10 million rupiahs as their first liquid resource. As soon as the game starts, the LO has a cell to decide. NLO has to decide whether to participate in MHBM. Then, LO has to choose a land management option. As described in Table 1, each option has consequences in terms of investment and return.

The game is designed to be played following the sequence $\mathrm{A}, \mathrm{B}$, and $\mathrm{C}$. The general challenge and objective of the players are to maximize the total returns, specifically cumulative revenue, in twenty time-steps, representing 20 years. Scenario A is designed to explore the situation where there is 
TABLE 1: Investment (I) and return (R) in millions rupiahs.

\begin{tabular}{|c|c|c|c|c|c|c|c|c|c|c|c|c|}
\hline \multirow[t]{2}{*}{ Year } & \multicolumn{2}{|c|}{$\begin{array}{l}\text { MHBM partnership } \\
\text { scheme }\end{array}$} & \multicolumn{2}{|c|}{$\begin{array}{l}\text { MHR partnership } \\
\text { scheme }\end{array}$} & \multicolumn{2}{|c|}{$\begin{array}{l}\text { Preserving old } \\
\text { rubber }\end{array}$} & \multicolumn{2}{|c|}{$\begin{array}{c}\text { Growing new clones } \\
\text { of rubber }\end{array}$} & \multicolumn{2}{|c|}{$\begin{array}{l}\text { Growing oil } \\
\text { palm }\end{array}$} & \multicolumn{2}{|c|}{$\begin{array}{c}\text { Growing mix } \\
\text { plantation }\end{array}$} \\
\hline & I & $\mathrm{R}$ & I & $\mathrm{R}$ & I & $\mathrm{R}$ & I & $\mathrm{R}$ & I & $\mathrm{R}$ & I & $\mathrm{R}$ \\
\hline 1 & 0 & 0 & 2 & 0 & 0 & 0 & 60 & 0 & 90 & 0 & 20 & 0 \\
\hline 2 & 0 & 0 & 0 & 0 & 0 & 0 & 0 & 0 & 0 & 0 & 2 & 0 \\
\hline 3 & 0 & 0 & 0 & 0 & 0 & 0 & 0 & 0 & 0 & 0 & 2 & 0 \\
\hline 4 & 0 & 0 & 0 & 0 & 0 & 0 & 0 & 0 & 0 & 0 & 2 & 0 \\
\hline 5 & 0 & 0 & 0 & 0 & 0 & 0 & 0 & 0 & 0 & 0 & 2 & 0 \\
\hline 6 & 0 & 0 & 0 & 0 & 0 & 0 & 0 & 60 & 0 & 90 & 2 & 0 \\
\hline 7 & 0 & 0 & 0 & 0 & 0 & 0 & 0 & 60 & 0 & 90 & 2 & 0 \\
\hline 8 & 0 & 5 & 0 & 80 & 0 & 0 & 0 & 60 & 0 & 90 & 2 & 0 \\
\hline 9 & 0 & 0 & 2 & 0 & 0 & 0 & 0 & 60 & 0 & 90 & 2 & 0 \\
\hline 10 & 0 & 0 & 0 & 0 & 0 & 0 & 0 & 60 & 0 & 90 & 2 & 0 \\
\hline 11 & 0 & 0 & 0 & 0 & 0 & 0 & 0 & 60 & 0 & 90 & 2 & 0 \\
\hline 12 & 0 & 0 & 0 & 0 & 0 & 0 & 0 & 48 & 0 & 72 & 2 & 0 \\
\hline 13 & 0 & 0 & 0 & 0 & 0 & 0 & 0 & 48 & 0 & 72 & 2 & 0 \\
\hline 14 & 0 & 0 & 0 & 0 & 0 & 0 & 0 & 48 & 0 & 72 & 2 & 0 \\
\hline 15 & 0 & 0 & 0 & 0 & 0 & 0 & 0 & 48 & 0 & 72 & 2 & 0 \\
\hline 16 & 0 & 5 & 0 & 80 & 0 & 0 & 0 & 48 & 0 & 72 & 2 & 0 \\
\hline 17 & 0 & 0 & 2 & 0 & 0 & 0 & 0 & 48 & 0 & 72 & 2 & 0 \\
\hline 18 & 0 & 0 & 0 & 0 & 0 & 0 & 0 & 36 & 0 & 54 & 2 & 0 \\
\hline 19 & 0 & 0 & 0 & 0 & 0 & 0 & 0 & 36 & 0 & 54 & 2 & 0 \\
\hline 20 & 0 & 0 & 0 & 0 & 0 & 0 & 0 & 36 & 0 & 54 & 20 & 600 \\
\hline
\end{tabular}

no communication among the players. In scenario B, players are divided into two groups (NLOs and LOs), and each group is organized into communication and collaboration subgroups. Finally, in scenario C, all players are in the same group; hence, they are able to communicate and possibly collaborate, if the players believe it will serve their own individual and collective interests.

The company can only afford four players to participate in the MHR scheme during the game. If there are more than four players who apply for the MHR scheme, the company will randomly choose and approve four.

Landscape diversity, an important indicator that should be monitored, can be calculated using average cell diversity following a simple algorithm as follows: (a) if a cell is a mix plantation, then the cell diversity is equal to $100 \%$; (b) if it is not a mix plantation, then the cell diversity is calculated by dividing the number of cell neighbors that have different land uses with the number of total neighbors; hence, cell diversity is between 0 and $100 \%$. Cell diversity affects fire risk in the area; hence, it should be monitored. If a cell has low cell diversity and it is planted with Acacia, then the probability of fire is high. Fire can spread out through the Acacia plantation cells via connected edges.

During and after the game, the game facilitator took note and presented the expected revenues to the players, the land diversity, and the emerging institutions in A, B, and C scenarios. The facilitator and the players can then react, share their views, and discuss the overall situation, including the need for institutions which may emerge during the game.

\section{Results and Discussion}

The game was pilot tested using university students at Bogor Agricultural University, Bogor, Indonesia. The experimental game was pilot tested with university students. The students were chosen in part because they are able to freely and genuinely express their ideas about the community's future livelihood options without being connected to these options. They are also able to quickly detect what livelihood options can improve the community's local economy. This situation supports the underlying assumption of the game (i.e., economic rationality). Using students in the experimental game has resulted in the improvement of the game due to the students' critical thinking skills. Students can be easily transformed into good game players in a virtual world such as in participatory simulation equipped with rules, experimentation, and scenario development in Colella [22].

Nevertheless, the students can be biased in their thinking about livelihoods vis-à-vis conservation. They may tend to be more idealistic than villagers in terms of putting conservation as more important than livelihoods. On the other hand, villagers are usually more deeply connected to their current works and life situations, and they tend to be less concerned about long-term consequences of different options without intensive facilitation. Intensive facilitation is necessary to ensure that they understand all possible options.

The experiment aimed at observing how the RPG approach, and the CORMAS-based model developed performance under the conditions of "implicit realism" described 


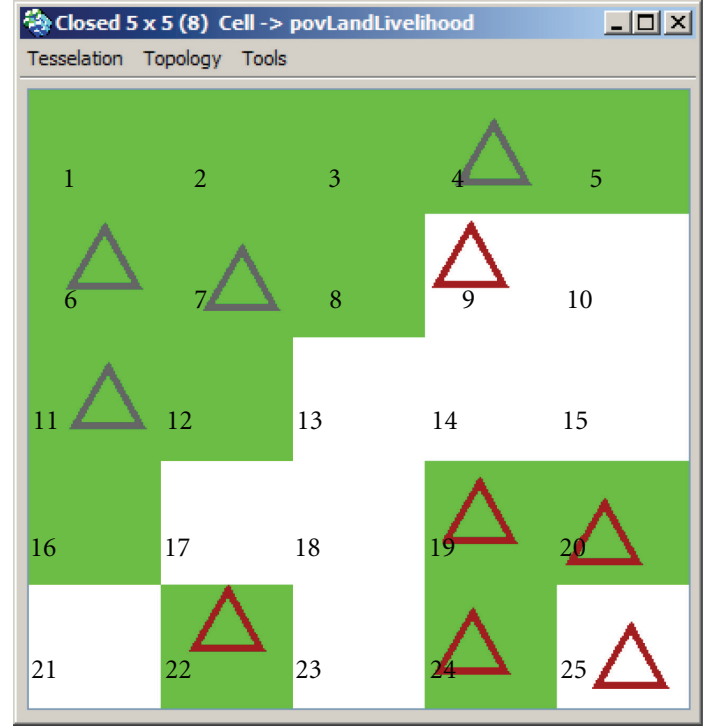

FIGURE 4: Scenario A: four players participate in MHBM scheme and the other four players participate in MHR scheme.

in Section 1.3. Hence, the RPG-CORMAS model was developed to reflect, as "close" as possible, the "rules," attitudes, behaviors, perspectives, and views of the local communities as observed and noted by the researchers during field visits to the site. Before doing the RPG study, the participants were briefed about RPG, what the experimental pilot study is about, the issues to be examined, and their "roles" in the RPG. The participants were not instructed, or guided in any way, about how the game was to be played by them. It was explained to them, however, that the objective of the experiment was to empirically examine "communitycompany partnerships," particularly different partnership arrangements and their relationships in the context of managing the resource. The participants were also asked to be available and participate throughout the stages, iterations, and applications of the RPG process.

To simplify the analysis, the players considered revenues from land management as the sole income source. The cost of money, such as commercial (bank) and noncommercial rates, was also not included in the analysis.

3.1. Scenario A: No Communication among the Game Players. The LO players do not have enough capital individually to invest in their land separately. As a result, six players tried to grow Acacia under the MHR scheme, but only four were accepted by MHP (Figure 4-cells 19, 20, 22, and 24). The four NLO players located on the concession land followed the MHBM scheme (cells 4, 6, 7, and 11). The total cumulative revenue for 20 years amounts to rupiahs 756 million for 10 players (see Table 2). As an initial approach, the total net revenue was chosen as a marker to compare the scenarios.

As shown in Table 2, the cumulative revenue of 40 million rupiahs for the four NLO players is calculated from their 10 million rupiahs initial capital. At year 8, Acacia reaches its rotation age and is harvested. Hence, each NLO player received a return (i.e., royalty) of 5 million rupiahs. Therefore, beginning year 9 , the cumulative income of the four NLO players is 60 million. The $6 \mathrm{LO}$ players, on the other hand, had 60 million initial capital. Four invested on the MHR scheme costing 8 million, and hence the cumulative revenue in year 1 is 52 million. At year 8 , the Acacia planted is harvested; hence, the $4 \mathrm{LO}$ players received a return of 320 million rupiahs.

Without communication, there was no opportunity for the players to pool their capital. Given the amount of capital each player has, joining MHR scheme was the rational choice for the LO players. Two LO players wanted but were not accepted to the MHR scheme because only four MHR applications are allowed by the company. NLO players kept their capital since they have no land to invest under the MHR scheme. Working individually, in fact, reflects the current situation in the communities surrounding the plantations. Lack of effective communication and trust made them act individually in dealing with their own livelihoods.

\subsection{Scenario B: Communication and Collaboration within} Each Group of Players. In scenario B, the LO and NLO players could communicate and collaborate within their groups. After some discussions, the two groups came up with two strategies. The NLO players representing the communities without land stayed with the MHBM scheme (Figure 5cells 2, 5, 7, and 16). Hence, there was no change in their cumulative revenues as shown in Table 3. The LO players representing communities with land agreed to invest all their money in rubber plantations (see Figure 5, cell 23). Establishing rubber plantations required an investment of rupiahs 60 million. The six LO players were able to put up the investment by pooling their capital. After 20 years, their cumulative return, which amounted to rupiahs 836 million, was better compared to scenario A (i.e., if they had invested in MHR-see Table 3).

Communication within each group increases the livelihood choices. Instead of acting individually, the LO players pooled their capital and established a new rubber plantation. Individually, each player does not have sufficient money to invest in his/her rubber plantation. This situation helps explain why most community rubber plantations now are old and unproductive. Collective action in the form of collective investment provides more choices to local communities.

\subsection{Scenario C: Communication and Collaboration among All} Players. In this scenario, all 10 players could communicate and collaborate. Hence, the players can evaluate each strategy with respect to their own individual interests, as well as their share in the "collective benefits," if they cooperate. They discussed different individual and collective strategies. The results are shown in Figure 6. Eventually, they selected a strategy, and came up with a plan to invest in oil palm (cell 19) which needed rupiahs 90 million as initial investments. Nine players pooled their resources to meet the initial investment cost. After 20 years, the cumulative return was about rupiahs 1184 million (see Table 4). 
TABle 2: The players' cumulative revenue under scenario A (million rupiahs).

\begin{tabular}{|c|c|c|c|c|c|c|c|}
\hline \multirow{2}{*}{ Time } & \multicolumn{3}{|c|}{ Without land (NLO) } & \multicolumn{3}{|c|}{ With land (LO) } & \multirow{2}{*}{ Total cumulative revenue } \\
\hline & Cumulative revenue & Invest & Return & Cumulative revenue & Invest & Return & \\
\hline 0 & 40 & 0 & 0 & 60 & 0 & 0 & 100 \\
\hline 1 & 40 & 0 & 0 & 52 & 8 & 0 & 92 \\
\hline 2 & 40 & 0 & 0 & 52 & 0 & 0 & 92 \\
\hline 3 & 40 & 0 & 0 & 52 & 0 & 0 & 92 \\
\hline 4 & 40 & 0 & 0 & 52 & 0 & 0 & 92 \\
\hline 5 & 40 & 0 & 0 & 52 & 0 & 0 & 92 \\
\hline 6 & 40 & 0 & 0 & 52 & 0 & 0 & 92 \\
\hline 7 & 40 & 0 & 0 & 52 & 0 & 0 & 92 \\
\hline 8 & 40 & 0 & 20 & 52 & 0 & 320 & 432 \\
\hline 9 & 60 & 0 & 0 & 364 & 8 & 0 & 424 \\
\hline 10 & 60 & 0 & 0 & 364 & 0 & 0 & 424 \\
\hline 11 & 60 & 0 & 0 & 364 & 0 & 0 & 424 \\
\hline 12 & 60 & 0 & 0 & 364 & 0 & 0 & 424 \\
\hline 13 & 60 & 0 & 0 & 364 & 0 & 0 & 424 \\
\hline 14 & 60 & 0 & 0 & 364 & 0 & 0 & 424 \\
\hline 15 & 60 & 0 & 0 & 364 & 0 & 0 & 424 \\
\hline 16 & 60 & 0 & 20 & 364 & 8 & 320 & 764 \\
\hline 17 & 80 & 0 & 0 & 676 & 0 & 0 & 756 \\
\hline 18 & 80 & 0 & 0 & 676 & 0 & 0 & 756 \\
\hline 19 & 80 & 0 & 0 & 676 & 0 & 0 & 756 \\
\hline 20 & 80 & 0 & 0 & 676 & 0 & 0 & 756 \\
\hline
\end{tabular}

TABLE 3: Scenario B: the players' cumulative revenue under scenario B (million rupiahs).

\begin{tabular}{|c|c|c|c|c|c|c|c|}
\hline \multirow{2}{*}{ Time } & \multicolumn{3}{|c|}{ Without land (NLO) } & \multicolumn{3}{|c|}{ With land (LO) } & \multirow{2}{*}{ Total cumulative revenue } \\
\hline & Cumulative revenue & Invest & Return & Cumulative revenue & Invest & Return & \\
\hline 0 & 40 & 0 & 0 & 60 & 0 & 0 & 100 \\
\hline 1 & 40 & 0 & 0 & 0 & 60 & 0 & 40 \\
\hline 2 & 40 & 0 & 0 & 0 & 0 & 0 & 40 \\
\hline 3 & 40 & 0 & 0 & 0 & 0 & 0 & 40 \\
\hline 4 & 40 & 0 & 0 & 0 & 0 & 0 & 40 \\
\hline 5 & 40 & 0 & 0 & 0 & 0 & 0 & 40 \\
\hline 6 & 40 & 0 & 0 & 0 & 0 & 60 & 100 \\
\hline 7 & 40 & 0 & 0 & 60 & 0 & 60 & 160 \\
\hline 8 & 40 & 0 & 20 & 120 & 0 & 60 & 240 \\
\hline 9 & 60 & 0 & 0 & 180 & 0 & 60 & 300 \\
\hline 10 & 60 & 0 & 0 & 240 & 0 & 60 & 360 \\
\hline 11 & 60 & 0 & 0 & 300 & 0 & 60 & 420 \\
\hline 12 & 60 & 0 & 0 & 360 & 0 & 48 & 468 \\
\hline 13 & 60 & 0 & 0 & 408 & 0 & 48 & 516 \\
\hline 14 & 60 & 0 & 0 & 456 & 0 & 48 & 564 \\
\hline 15 & 60 & 0 & 0 & 504 & 0 & 48 & 612 \\
\hline 16 & 60 & 0 & 20 & 552 & 0 & 48 & 680 \\
\hline 17 & 80 & 0 & 0 & 600 & 0 & 48 & 728 \\
\hline 18 & 80 & 0 & 0 & 648 & 0 & 36 & 764 \\
\hline 19 & 80 & 0 & 0 & 684 & 0 & 36 & 800 \\
\hline 20 & 80 & 0 & 0 & 720 & 0 & 36 & 836 \\
\hline
\end{tabular}


TABLE 4: The players' cumulative revenue under scenario C (million rupiahs).

\begin{tabular}{|c|c|c|c|c|c|c|c|}
\hline \multirow{2}{*}{ Time } & \multicolumn{3}{|c|}{ Without land (NLO) } & \multicolumn{3}{|c|}{ With land (LO) } & \multirow{2}{*}{ Total cumulative revenue } \\
\hline & Cumulative revenue & Invest & Return & Cumulative revenue & Invest & Return & \\
\hline 0 & 40 & 0 & 0 & 60 & 0 & 0 & 100 \\
\hline 1 & 10 & 0 & 0 & 0 & 90 & 0 & 10 \\
\hline 2 & 10 & 0 & 0 & 0 & 0 & 0 & 10 \\
\hline 3 & 10 & 0 & 0 & 0 & 0 & 0 & 10 \\
\hline 4 & 10 & 0 & 0 & 0 & 0 & 0 & 10 \\
\hline 5 & 10 & 0 & 0 & 0 & 0 & 0 & 10 \\
\hline 6 & 10 & 0 & 0 & 0 & 0 & 90 & 100 \\
\hline 7 & 10 & 0 & 0 & 90 & 0 & 90 & 190 \\
\hline 8 & 10 & 0 & 20 & 180 & 0 & 90 & 300 \\
\hline 9 & 30 & 0 & 0 & 270 & 0 & 90 & 390 \\
\hline 10 & 30 & 0 & 0 & 360 & 0 & 90 & 480 \\
\hline 11 & 30 & 0 & 0 & 450 & 0 & 90 & 570 \\
\hline 12 & 30 & 0 & 0 & 540 & 0 & 72 & 642 \\
\hline 13 & 30 & 0 & 0 & 612 & 0 & 72 & 714 \\
\hline 14 & 30 & 0 & 0 & 684 & 0 & 72 & 786 \\
\hline 15 & 30 & 0 & 0 & 756 & 0 & 72 & 858 \\
\hline 16 & 30 & 0 & 20 & 828 & 0 & 72 & 950 \\
\hline 17 & 50 & 0 & 0 & 900 & 0 & 72 & 1022 \\
\hline 18 & 50 & 0 & 0 & 972 & 0 & 54 & 1076 \\
\hline 19 & 50 & 0 & 0 & 1026 & 0 & 54 & 1130 \\
\hline 20 & 50 & 0 & 0 & 1080 & 0 & 54 & 1184 \\
\hline
\end{tabular}

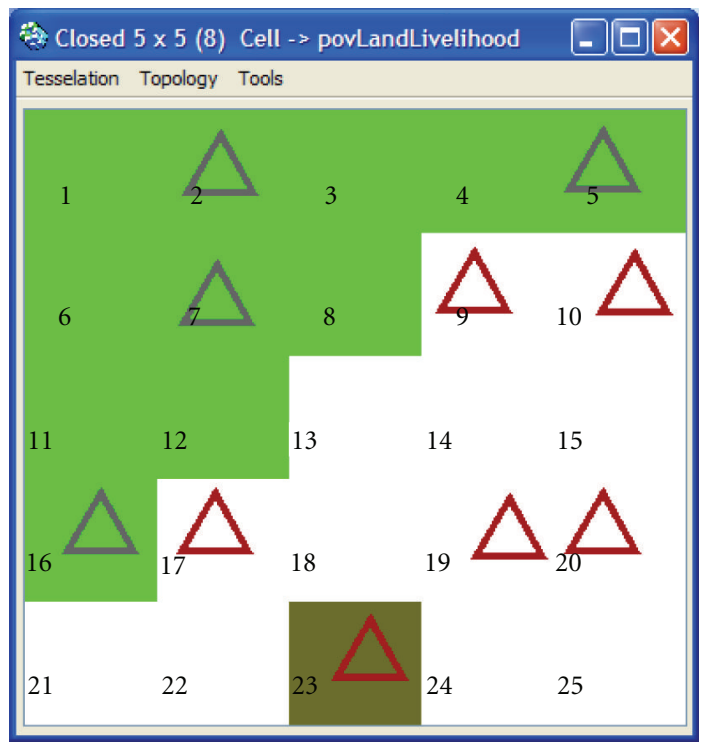

Figure 5: Scenario B: six players with land pool their money to invest in rubber plantations.

The game was iterated twice. In the case of scenarios A and $\mathrm{B}$, the players came up with the same strategy in the second iteration. This is not the case with scenario $\mathrm{C}$ where the players came up with a different strategy in the second iteration. Instead of investing all their money in oil palm, they decided to have two kinds of investments: MHR (cells

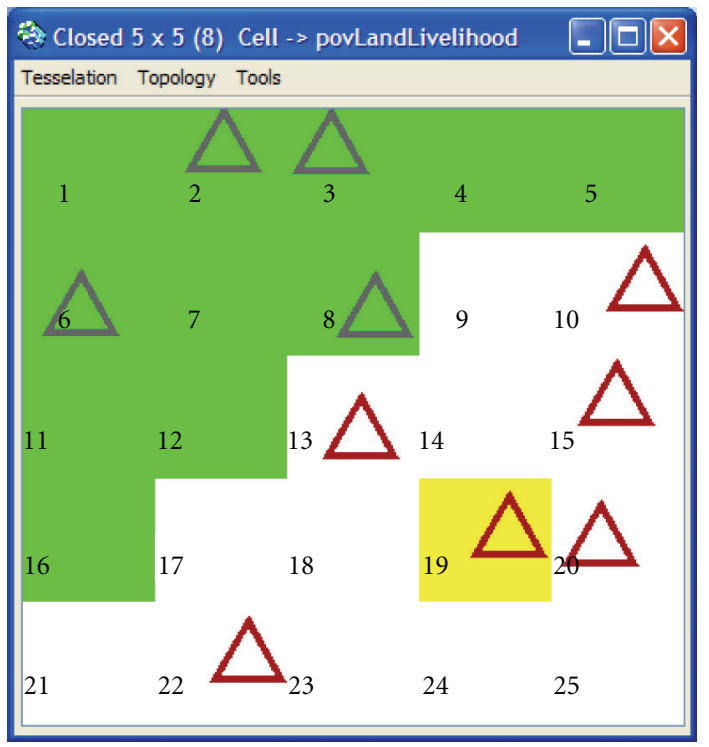

Figure 6: Scenario C: nine players pool their money to invest in oil palm plantation.

20, 22, and 23) and rubber plantation (see cell 9-Figure 7). As a result, after 20 years, their net revenue was higher than in previous scenarios (see Table 5).

Figure 8 describes a comparative diagram of the cumulative revenues associated with each scenario. The net present values (NPVs) of these scenarios, at $8 \%$ and $12 \%$ 
TABLE 5: The players' cumulative revenue under scenario C1 (million rupiahs).

\begin{tabular}{|c|c|c|c|c|c|c|c|}
\hline \multirow{2}{*}{ Time } & \multicolumn{3}{|c|}{ Without land (NLO) } & \multicolumn{3}{|c|}{ With land (LO) } & \multirow{2}{*}{ Total cumulative revenue } \\
\hline & Cumulative revenue & Invest & Return & Cumulative revenue & Invest & Return & \\
\hline 0 & 40 & 0 & 0 & 60 & 0 & 0 & 100 \\
\hline 1 & 34 & 0 & 0 & 0 & 66 & 0 & 34 \\
\hline 2 & 34 & 0 & 0 & 0 & 0 & 0 & 34 \\
\hline 3 & 34 & 0 & 0 & 0 & 0 & 0 & 34 \\
\hline 4 & 34 & 0 & 0 & 0 & 0 & 0 & 34 \\
\hline 5 & 34 & 0 & 0 & 0 & 0 & 0 & 34 \\
\hline 6 & 34 & 0 & 0 & 0 & 0 & 60 & 94 \\
\hline 7 & 34 & 0 & 0 & 60 & 0 & 60 & 154 \\
\hline 8 & 34 & 0 & 20 & 120 & 0 & 300 & 474 \\
\hline 9 & 54 & 0 & 0 & 414 & 6 & 60 & 528 \\
\hline 10 & 54 & 0 & 0 & 474 & 0 & 60 & 588 \\
\hline 11 & 54 & 0 & 0 & 534 & 0 & 60 & 648 \\
\hline 12 & 54 & 0 & 0 & 594 & 0 & 48 & 696 \\
\hline 13 & 54 & 0 & 0 & 642 & 0 & 48 & 744 \\
\hline 14 & 54 & 0 & 0 & 690 & 0 & 48 & 792 \\
\hline 15 & 54 & 0 & 0 & 738 & 0 & 48 & 840 \\
\hline 16 & 54 & 0 & 20 & 786 & 0 & 288 & 1148 \\
\hline 17 & 74 & 0 & 0 & 1068 & 6 & 48 & 1190 \\
\hline 18 & 74 & 0 & 0 & 1116 & 0 & 36 & 1226 \\
\hline 19 & 74 & 0 & 0 & 1152 & 0 & 36 & 1262 \\
\hline 20 & 74 & 0 & 0 & 1188 & 0 & 36 & 1298 \\
\hline
\end{tabular}

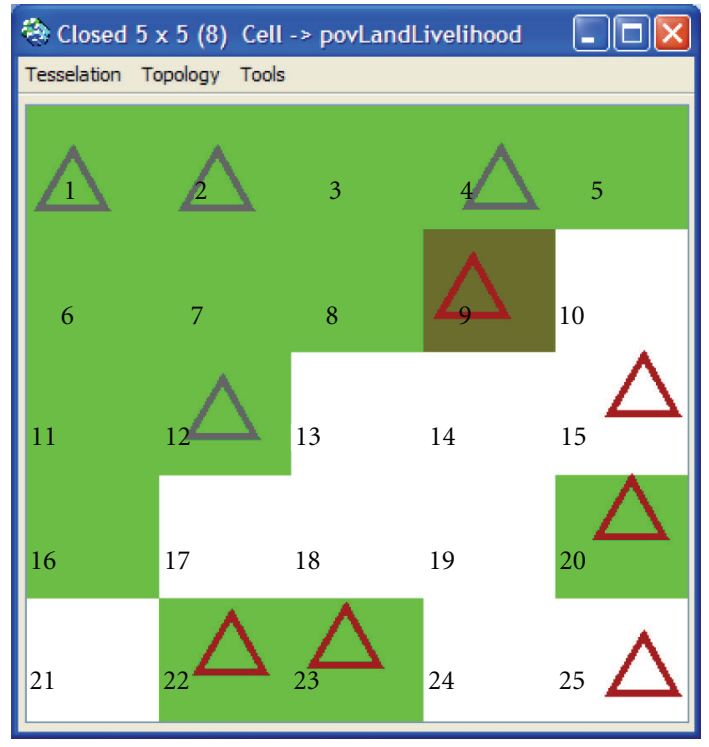

FIGURE 7: Scenario C1: six players invest in rubber plantation (cell 9), and the other three players invest in MHR (cells 20, 22, and 23).

interest rates, are summarized in Table 6 . The table shows that scenario $\mathrm{C} 1$ is the most profitable option with the highest NPV. Scenario C also gave consistently higher NPVs compared to scenarios A and B. Scenario A has a higher NPV than scenario B at $12 \%$ mainly because of its high revenue

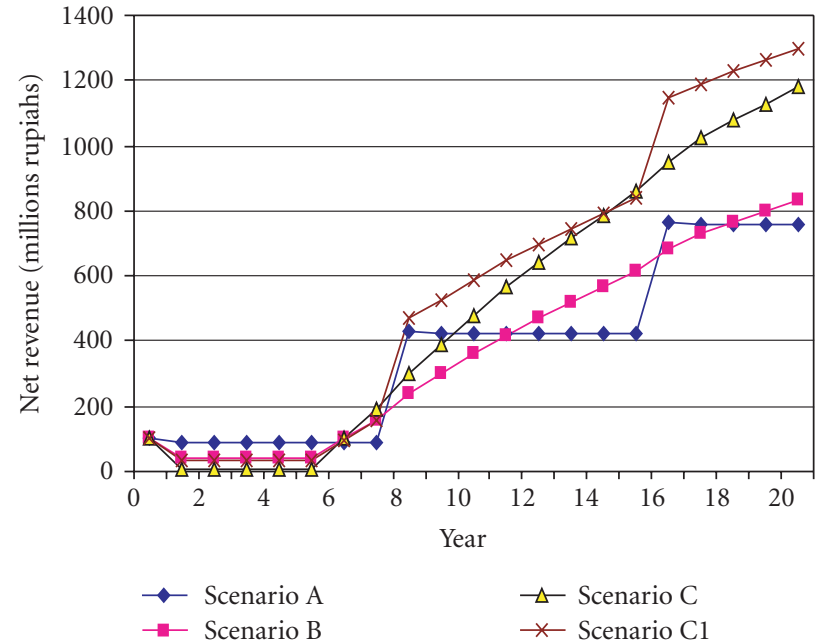

Figure 8: The total net revenue collected by 10 players during 20 years (in million rupiahs) for Scenario A, B, C and C1.

values early in the rotation. Scenario B has a higher NPV value than scenario $\mathrm{A}$ at lower interest rates (e.g., $8 \%$ ).

The relative land diversities for scenarios $\mathrm{A}, \mathrm{B}, \mathrm{C}$, and $\mathrm{C} 1$ were $40.8,27.9,27.6$, and 34.9 , respectively. It was assumed that the land outside MHP forest was homogeneous, and that even though planted with Acacia (scenario A), diversity would increase. However, the probability of fires during the period of community investment is lower in scenarios B and 
TABLE 6: Saving and returns for each scenario (million rupiahs).

\begin{tabular}{|c|c|c|c|c|c|c|c|c|}
\hline \multirow{2}{*}{ Time $(t)$} & \multicolumn{2}{|c|}{ Scenario A } & \multicolumn{2}{|c|}{ Scenario B } & \multicolumn{2}{|c|}{ Scenario C } & \multicolumn{2}{|c|}{ Scenario C1 } \\
\hline & Cumulative & $\begin{array}{l}\text { Saving and } \\
\text { return at } \\
\text { time } t\end{array}$ & Cumulative & $\begin{array}{l}\text { Saving and } \\
\text { return at } \\
\text { time } t\end{array}$ & Cumulative & $\begin{array}{l}\text { Saving and } \\
\text { return at } \\
\text { time } t\end{array}$ & Cumulative & $\begin{array}{l}\text { Saving and } \\
\text { return at } \\
\text { time } t\end{array}$ \\
\hline 0 & 100 & 100 & 100 & 100 & 100 & 100 & 100 & 100 \\
\hline 1 & 92 & 92 & 40 & 40 & 10 & 10 & 34 & 34 \\
\hline 2 & 92 & 0 & 40 & 0 & 10 & 0 & 34 & 0 \\
\hline 3 & 92 & 0 & 40 & 0 & 10 & 0 & 34 & 0 \\
\hline 4 & 92 & 0 & 40 & 0 & 10 & 0 & 34 & 0 \\
\hline 5 & 92 & 0 & 40 & 0 & 10 & 0 & 34 & 0 \\
\hline 6 & 92 & 0 & 100 & 60 & 100 & 90 & 94 & 60 \\
\hline 7 & 92 & 0 & 160 & 60 & 190 & 90 & 154 & 60 \\
\hline 8 & 432 & 340 & 240 & 80 & 300 & 110 & 474 & 320 \\
\hline 9 & 424 & -8 & 300 & 60 & 390 & 90 & 528 & 54 \\
\hline 10 & 424 & 0 & 360 & 60 & 480 & 90 & 588 & 60 \\
\hline 11 & 424 & 0 & 420 & 60 & 570 & 90 & 648 & 60 \\
\hline 12 & 424 & 0 & 468 & 48 & 642 & 72 & 696 & 48 \\
\hline 13 & 424 & 0 & 516 & 48 & 714 & 72 & 744 & 48 \\
\hline 14 & 424 & 0 & 564 & 48 & 786 & 72 & 792 & 48 \\
\hline 15 & 424 & 0 & 612 & 48 & 858 & 72 & 840 & 48 \\
\hline 16 & 764 & 340 & 680 & 68 & 950 & 92 & 1148 & 308 \\
\hline 17 & 756 & -8 & 728 & 48 & 1022 & 72 & 1190 & 42 \\
\hline 18 & 756 & 0 & 764 & 36 & 1076 & 54 & 1226 & 36 \\
\hline 19 & 756 & 0 & 800 & 36 & 1130 & 54 & 1262 & 36 \\
\hline 20 & 756 & 0 & 836 & 36 & 1184 & 54 & 1298 & 36 \\
\hline NPV & & 583 & & 697 & & 1,028 & & 1,108 \\
\hline
\end{tabular}

C because both scenarios did not involve Acacia plantations. Scenario C1, which is more profitable than scenario C, also has higher landscape diversity than scenario C.

The game shows that communication and collaboration among the players can produce more options to improve the communities' livelihood by their resources. Through this collaboration, collective investment can emerge. It is easy to see that rubber plantations are more profitable than the MHR scheme; however, people in South Sumatra currently cannot renew their rubber smallholdings for the lack of the required capital amounting to rupiahs 6 million per hectare. If they can anticipate the net return of collective investment, then they may realize that there is a chance for future renewal.

If this collective action is extended to community members without land who are currently working for the MHBM scheme, their net return will even be higher. In the first game iteration, they collaboratively planted oil palm, but in the second they concurrently planted rubber and participated in the MHR scheme. From the simple case study, one can see evidence of the learning process through playing the game. It is hard to determine whether an optimum solution will emerge automatically if they cooperate, but it is possible that the optimum solution will be discovered over time. Regardless optimality of chosen strategy is not as important as social acceptability of chosen strategy. In a case as complex as the problem addressed in this case study, "pareto optimality" may only exist theoretically, but may be too elusive, if not impossible, to determine.

3.4. Institutional Implications. Communication had been shown to be an effective mechanism for increasing the likelihood that stakeholders choose benefit-sharing strategies. For instance, in this study, communication facilitated through RPG enabled the players to explore various strategies that increased their cumulative incomes. These collective strategies emerged, in part, from the participants' realization that they might get better returns given the payoff structure and if they collaborate and develop a group strategy.

The experiment demonstrated the importance of communication and its potential in increasing community benefits. This is particularly true when communication is provided as a mechanism for the players to envisage a coordinated strategy. For instance, in this experimental pilot study, an ex-postapplication of RPG at the community led to the formation of communication institutions such as a community forum at the village level and a multistakeholder forum at the district level. However, community institutions are not costless and are not formed easily and quickly. The community and other stakeholders need to invest time and effort to establish these forums or arenas. This is particularly 
significant because the communities surrounding the MHP plantations, used as the experimental case study, are subsistence community where most people live poorly with less than 1 USD per day [23]. Hence, the MHP plantations influence the traditional livelihoods of the community. Therefore, the level of cooperation among community members may be strongly influenced by inherent competition among the communities for the benefits derived from the plantations. This makes the formation of community forums even more difficult, but strategically significant.

Communication among community members as well as the effort to arrive at a coordinated strategy may slow the decision-making process seeking fruitful partnership with MHP. However, since forest- and land-related activities are long-term investments, and realizing that impatience may undermine long-term social and ecological sustainability [17], a slower and more deliberate decision-making process particularly at the beginning is reasonable.

Coordinated strategy involves producing rules for sharing benefit and cost of any land use option. In the case study, the establishment of a communication institution, such as a formal forum, was deemed critical to the enforcement of these rules. Without this rule enforcement capability, problems related to free riders and rent seekers can emerge easily. Moreover, the problem of elite capture as described by Platteau and Gaspart [16] can also diminish. Learning from RPG experiment, the real stakeholders in Muara Enim District agreed to establish a forum, called "Forum Sebahu Sejalan." This forum was equipped with an explicit constitution and rule, called anggaran dasar and anggaran rumah tangga, to guide the organization and execution of the forum.

The forum is envisioned to serve as a mechanism to bridge the community and MHP's interests. Through the coordinated strategy, and particularly the formal forum, the community is positioned in an environment, where they are able to bargain and negotiate with MHP. On the other hand, MHP also benefits from the forum through reducing transaction cost of negotiation. Without the formal forum, MHP traditionally deals with individual community members and leaders. With the formal forum, a more balanced partnership can emerge from discussions between community members, united by the common strategy, and MHP. For instance, in an ex-postapplication of RPG, MHP has agreed to give a more transparent figure about the overall plantation costs and returns in response to requests made by the community. MHP also agreed to lend money to the community to enable them to make better land use investments as well as pursue small plantation operational contracts with MHP such as weeding and harvesting. This balanced and transparent partnership can only make the partnership more resilient. The forum provides both parties with a common ground to negotiate about regular issues such as profit sharing at the end of rotation, as well as sensitive issues such as land property ownership and access to resources.

In the case study, the "Forum Sebahu Sejalan" is also a place where the local government of Muara Enim, South Sumatra communicates and negotiates with community members and representatives. At the same time, local community can participate and influence policy formulation on forest plantations such as benefit sharing, plantation extent, production targets, and location. This forum is envisioned as a mechanism to make the decentralization policies work better for forest plantations at the district level. The forum, its constitution, and rules play a role as institutional mechanisms that can encourage the local community to cooperate with government officials and to promote more interactions between less powerful community members and government officials.

\section{Conclusion}

This paper described an experiment that examines the RPG method and how it can be used by stakeholders to explore community-company partnerships. Based on the experiences gained from the experimental case study, one can conclude that the RPG method can help explore these partnerships, make them more transparent, and create win-win scenarios for all stakeholders. From the simple case study, the following were noted: (a) CORMAS is a useful platform to develop and carry out simple spatially explicit role-playing game (RPG), (b) collaboration and communication can design collective strategies that help improve community livelihoods in the future, (c) the best solutions, or win-win relationships among stakeholders, can be learned over continual RPG iteration, and (d) RPG game can help players anticipate potential outcomes of their own decisions.

Role-playing game gave players insight into how collective investment is preferable to improve their future livelihoods. The players learned as they discussed, played, and analyzed the game. The game mimicked the interaction between communities living near the MHP forest plantations, although it was simplified so that the exercise might be applied to partnerships involving other local communities and forest plantation companies. The results from the game also provided the rationale to establish a costless communication institution called "Forum Sebahu Sejalan" in the District of Muara Enim, South Sumatra . The forum can play a significant role in building more resilient relationship between local community and MHP. At the same time, the forum acts as avenue for local community to access the government officials and to make decentralization works better in forest plantations at the district and the village levels.

\section{Acknowledgments}

This study was funded by the "Levelling the Playing Field project" through a grant from the European Union managed by the Centre de Coopération Internationale en Recherche Agronomique pour le Développement (CIRAD), Center for International Forestry Research, Bogor, Indonesia (CIFOR), and the University of Illinois. However, opinions expressed herein are solely of the authors and do not necessarily reflect the views of CIRAD and CIFOR. 


\section{References}

[1] M. Sakai, "Land dispute resolution in the political reform at the time of decentralization in Indonesia," Journal of Antropologi Indonesia, pp. 15-32, 2002.

[2] F. O. Bousquet, C. Barreteau, C. Le Page, and C. Mullon, "An environmental modeling approach: the use of multi-agent simulations," in Advances in Environmental and Ecological Modelling, F. Blasco and A. Weill, Eds., Elsevier, Paris, France, 1999.

[3] S. Ossowski, Coordination in Artificial Agent Societies: Social Structures and Its Implications for Autonomous Problem Solving Agents, Springer, Berlin, Germany, 1999.

[4] G. Weiss, Ed., Multi Agent Systems: A Modern Approach to Distributed Artificial Intelligence, MIT Press, Cambridge, Mass, USA, 1999.

[5] R. Axelrod and M. D. Cohen, Harnessing Complexity: Organizational Implications of a Scientific Frontier, The Free Press, New York, NY, USA, 1999.

[6] COMMOD, "Companion Modeling and Resilience of Ecosystems in Southeast Asia: Principles and Tools," Chulalongkorn University, Thailand: Companion Modelling Training Materials, December 2004.

[7] G. Romp, Game Theory: Introduction and Applications, Oxford University Press, Oxford, UK, 1997.

[8] D. J. Cooper, J. H. Kagel, W. Lo, and Q. L. Gu, "Gaming against managers in incentive systems: experimental results with Chinese students and Chinese managers," American Economic Review, vol. 89, no. 4, pp. 781-804, 1999.

[9] E. Ostrom, R. Gardner, and J. Walker, Rules, Games and Common-Pool Resources, The University of Michigan Press, Ann Arbor, Mich, USA, 1994.

[10] J.-C. Cárdenas and E. Ostrom, "What do people bring into the game? Experiments in the field about cooperation in the commons," Agricultural Systems, vol. 82, no. 3, pp. 307-326, 2004.

[11] R. Meinzen-Dick, M. DiGregorio, and N. McCarthy, "Methods for studying collective action in rural development," Agricultural Systems, vol. 82, no. 3, pp. 197-214, 2004.

[12] P. Pacheco, J. Motloch, and J. Vann, "Second Chance Game: local (university-community) partnerships for global awareness and responsibility," Journal of Cleaner Production, vol. 14, no. 9-11, pp. 848-854, 2006.

[13] S. Atran, D. L. Medin, and N. O. Ross, "The cultural mind: environmental decision making and cultural modeling within and across populations," Psychological Review, vol. 112, no. 4, pp. 744-776, 2005.

[14] S. Kant and J. C. Nautiyal, "Sustainable joint forest management through bargaining: a bilateral monopoly gaming approach," Forest Ecology and Management, vol. 65, no. 2-3, pp. 251-264, 1994.

[15] A. A. Nawir, L. Santoso, and I. Mudhofar, Towards MutuallyBeneficial Company-Community Partnerships in Timber Plantation: Lessons Learnt from Indonesia, CIFOR, Bogor, Indonesia, 2003.

[16] J.-P. Platteau and F. Gaspart, "The risk of resource misappropriation in community-driven development," World Development, vol. 31, no. 10, pp. 1687-1703, 2003.

[17] J. C. Ribot, "Choose democracy: environmentalists' sociopolitical responsibility," Global Environmental Change, vol. 16, no. 2, pp. 115-119, 2006.

[18] P. Ho, "Credibility of institutions: forestry, social conflict and titling in China," Land Use Policy, vol. 23, no. 4, pp. 588-603, 2006.
[19] A. Agrawal and C. C. Gibson, "Enchantment and disenchantment: the role of community in natural resource conservation," World Development, vol. 27, no. 4, pp. 629-649, 1999.

[20] CIRAD, "Natural resources and multi-agent simulations," 2001, http://cormas.cirad.fr/en/outil/outil.htm.

[21] T. Lynam, F. Bousquet, C. Le Page, et al., "Adapting science to adaptive managers: spidergrams, belief models, and multiagent systems modeling," Conservation Ecology, vol. 5, no. 2, p. 24, 2002.

[22] V. Colella, "Participatory simulations: building collaborative understanding through immersive dynamic modeling," Journal of the Learning Sciences, vol. 9, no. 4, pp. 471-500, 2000.

[23] P. Levang and S. Sitorus, "Rubber smallholders versus acacia growers: socio-economic survey on the Rambang Dangku Sub-District," Bogor: LPF Project working paper, 2006. 

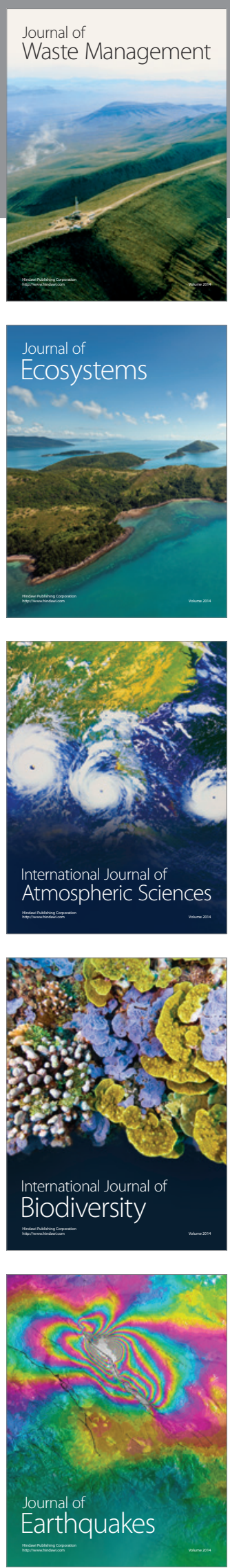
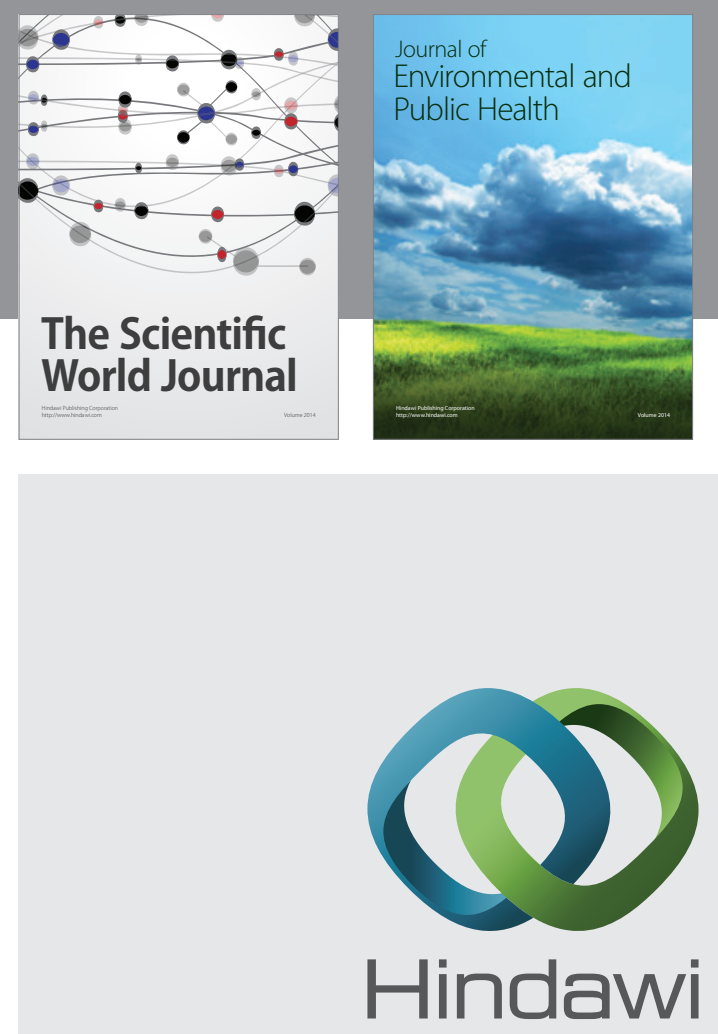

Submit your manuscripts at

http://www.hindawi.com
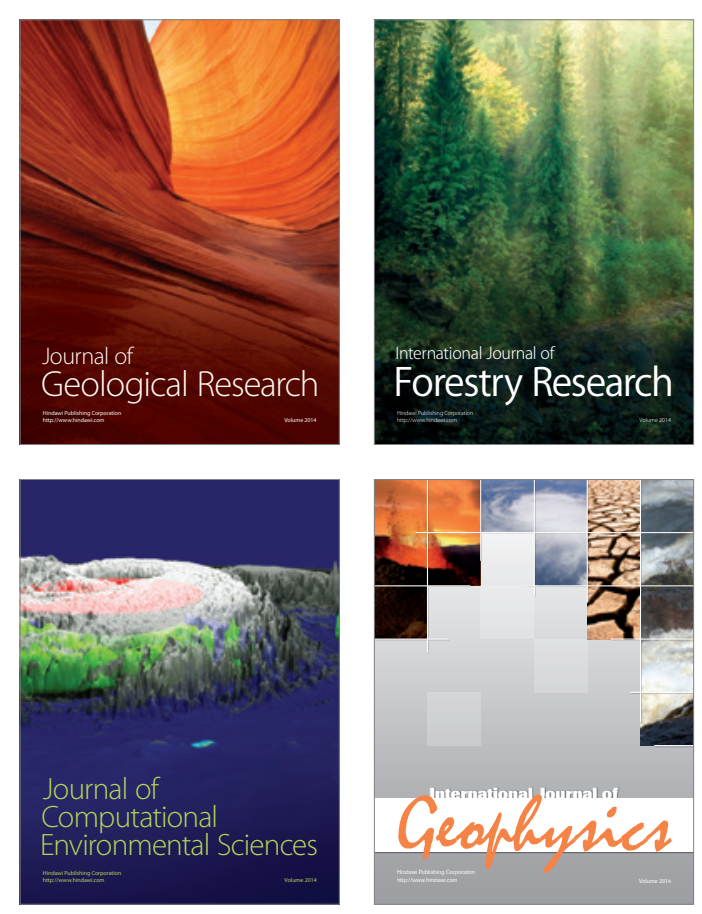
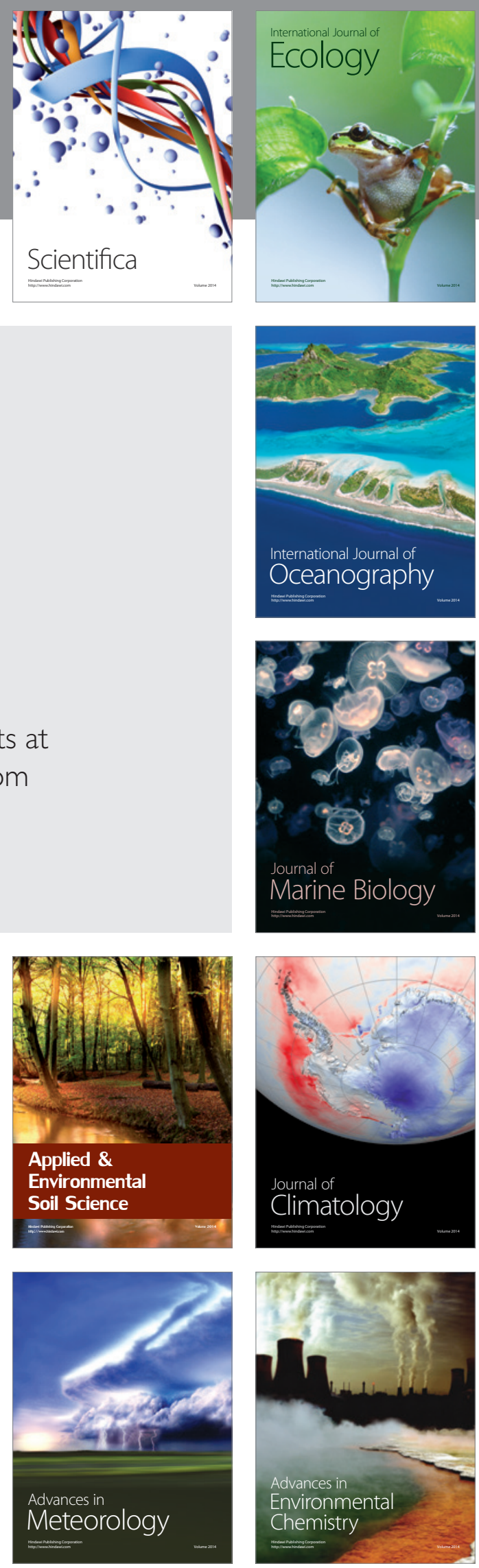